\author{
Sławomir Dorocki, Anna Irena Szymańska, Małgorzata Zdon-Korzeniowska \\ Uniwersytet Pedagogiczny \\ im. Komisji Edukacji Narodowej \\ w Krakowie
}

\title{
Polskie gospodarstwa agroturystyczne w dobie kryzysu gospodarczego
}

\author{
Polish agritourism farms in times of an economic crisis
}

\begin{abstract}
Streszczenie
Kryzys gospodarczy ostatnich kilku lat dotknął w większym lub mniejszym stopniu każdej branży gospodarki światowej. W Polsce określone uwarunkowania oraz polityka państwa spowodowały, że gospodarka wykazała się znaczną, w stosunku do innych krajów, odpornością na kryzys (Sawicka, 2011). Jak podkreślają eksperci, znaczny wpływ na taki stan rzeczy mieli nasi rodzimi przedsiębiorcy, którzy nie poddali się pesymistycznym nastrojom. Okres spowolnienia gospodarczego dla przedsiębiorców jest czasem trudnym, ale i, jak zauważa A. Sawicka (2011), niezwykle mobilizującym, zmusza ich on bowiem do rewizji własnych celów oraz podjęcia zmian - zarówno w odniesieniu do zarządzania własnym przedsiębiorstwem, jak i w odniesieniu do rynku.

Przedmiotem analizy w niniejszym referacie jest działalność gospodarstw agroturystycznych, ze szczególnym uwzględnieniem ich zachowań rynkowych i przedsiębiorczych w dobie kryzysu gospodarczego. Analizy dokonano na podstawie wyników badań przeprowadzonych na grupie gospodarstw agroturystycznych z całej Polski. Badania miały m.in. na celu rozpoznanie, czy respondenci dostrzegają jakieś zmiany w funkcjonowaniu swojego gospodarstwa, a w efekcie, czy odczuwają w jakimś stopniu wpływ kryzysu gospodarczego na funkcjonowanie prowadzonych przez nich przedsiębiorstw agroturystycznych.
\end{abstract}

\begin{abstract}
The economic crisis of the last few years has affected each sector of the world economy in some way. Specific conditions and governmental policy introduced in Poland meant that, in comparison to other countries, the economy demonstrated considerable resistance to the crisis (Sawicka, 2011). As experts point out, a significant impact in this area was made by Polish entrepreneurs, who did not give in to the pessimistic mood. For businesses, the period of economic downturn is difficult, but also, as noted by A. Sawicka (2011), extremely mobilising. This is due to the fact that crises force the owners to review their goals and implement changes - both in relation to the management of their own company, as well as in relation to the market.

The subjects of the analysis in this paper are agritourism activities, with particular emphasis on the market and entrepreneurial behaviour in times of economic crisis. The analysis was based on the results of research, conducted on a group of agritourism farms from across Poland. These studies were to identify whether respondents notice any changes in the operation of their farms, and, as a result, whether they feel any impact of the economic crisis on the functioning of these agritourism enterprises.
\end{abstract}

Słowa kluczowe: agroturystyka; gospodarstwa agroturystyczne; innowacyjność; przedsiębiorczość; kryzys gospodarczy; rodzinność

Key words: agritourism; agritourism farms; innovation; entrepreneurship; economic crisis; family environment 


\section{Wprowadzenie}

Światowy kryzys gospodarczy, którego pierwsze skutki zaczęto dostrzegać w 2008 r., dotyczył w mniejszym lub większym stopniu każdej branży gospodarki światowej. Jak pokazują analizy wielkości charakteryzujących kondycję rynku turystycznego, najwyraźniej skutki dekoniunktury gospodarczej w branży turystycznej ujawniły się w 2009 r. (Zdon-Korzeniowska, Rachwał, 2010). W Polsce określone uwarunkowania oraz polityka państwa spowodowały, że gospodarka wykazała się znaczną, w stosunku do innych krajów, odpornością na kryzys (Sawicka, 2011). Jak podkreślają eksperci, znaczny wpływ na taki stan rzeczy mieli nasi rodzimi przedsiębiorcy, którzy nie poddali się pesymistycznym nastrojom.

Przedmiotem analizy w niniejszym referacie jest działalność gospodarstw agroturystycznych, ze szczególnym uwzględnieniem ich zachowań rynkowych i przedsiębiorczych w dobie kryzysu gospodarczego. Realizacja powyższych celów oparta została na analizie literatury przedmiotu, wyników badań obcych oraz własnych badań bezpośrednich z wykorzystaniem techniki bezpośredniego wywiadu kwestionariuszowego. Badania własne Autorów były przeprowadzone z wykorzystaniem techniki bezpośredniego wywiadu kwestionariuszowego w okresie od stycznia do marca 2012 r. na obszarze całej Polski. Ankiety rozesłano droga e-mailową do grupy 1330 gospodarstw agroturystycznych z całej Polski. Zwrot kształtował się na poziomie 46 kwestionariuszy ankiet (46 kwestionariuszy ankiet było kompletnie i poprawnie wypełnionych i tylko te zostały poddane dalszej analizie).

\section{Przedsiębiorstwa agroturystyczne w Polsce}

Aktywność agroturystyczna cieszy się rosnącym zainteresowaniem zarówno w naszym kraju, jak i w innych państwach Unii Europejskiej. Jej popularność widoczna jest nie tylko od strony popytowej, gdzie ceniona jest jako atrakcyjna forma spędzania czasu wolnego, ale również od strony podażowej - jako alternatywna forma działalności rolniczej obejmująca ofertę pobytu u rodzin wiejskich prowadzących gospodarstwa rolne oraz zróżnicowane formy rekreacji w oparciu o specyficzne walory obszarów wiejskich (Dorocki, Zdon-Korzeniowska, 2012). W Polsce po okresie transformacji i nastaniu gospodarki wolnorynkowej typowa działalność rolnicza napotkała znaczące trudności związane m.in. z możliwością zbytu płodów rolnych, niskimi cenami i rosnącymi kosztami produkcji rolnej, co doprowadziło do nieefektywności i likwidacji znacznej części gospodarstw rolnych. Naturalną konsekwencją tego stanu rzeczy było poszukiwanie przez rolników nowych, alternatywnych form działalności i zarobkowania. Jedną z nich stała się właśnie agroturystyka.

Obserwuje się systematyczny wzrost liczby gospodarstw agroturystycznych (tab. 1.). Według danych za 2011 r. w Polsce funkcjonują ok. 7852 gospodarstwa agroturystyczne dysponujące łącznie 82694 miejscami noclegowymi. Stanowi to niemal 20-procentowy wzrost liczby gospodarstw agroturystycznych oraz prawie 55-procentowy wzrost liczby miejsc noclegowych w stosunku do $2002 \mathrm{r}$.

Zdecydowanie najwięcej gospodarstw agroturystyczny znajduje się w gminach należących do województw: małopolskiego i podkarpackiego. Nieco mniej (choć nadal stosunkowo dużo) gospodarstw agroturystycznych zlokalizowanych jest w województwach: warmińsko-mazurskim, dolnośląskim, pomorskim i podlaskim. Największy, bo aż ponad 250-procentowy przyrost liczby tych gospodarstw w stosunku do 2002 r. odnotowano w województwie kujawsko-pomorskim, ponad 80-procentowe przyrosty nastąpiły również w województwach dolnośląskim, podkarpackim i śląskim. Niektóre z województw odnotowały jednak zmniejszenie się liczby gospodarstw agroturystycznych. Około 50-procentowe spadki widoczne są w województwach lubuskim i mazowieckim, o ok. 25\% spadła również liczba gospodarstw agroturystycznych w województwie warmińsko-mazurskim i o 2,4\% w województwie podlaskim. 
We wszystkich województwach z wyjątkiem dolnośląskiego procentowa zmiana liczby miejsc noclegowych była większa niż procentowa zmiana liczby gospodarstw agroturystycznych. Ponadto, również w tych w województwach, w których odnotowano spadek liczby gospodarstw agroturystycznych (z wyjątkiem lubuskiego) odnotowano przyrost liczby miejsc noclegowych. Fakty te świadczą o zwiększeniu przez poszczególne gospodarstwa agroturystyczne swojej pojemności, tj. liczby oferowanych miejsc noclegowych.

Ogólnie można przyjąć, że podmioty oferujące usługi agroturystyczne (gospodarstwa agroturystyczne) w Polsce funkcjonują (Dorocki, Szymańska, Zdon-Korzeniowska, 2012):

- w ramach gospodarstw rolnych lub też

- są indywidualną działalnością gospodarczą prowadzoną na własny rachunek, zgodnie z zapisami ustawy o swobodzie działalności gospodarczej oraz ustawy o podatku dochodowym i w różnych formach organizacyjno-prawnych.

W drugim wypadku bez wątpienia możemy mówić o przedsiębiorstwach. Działalność agroturystyczna prowadzona w ramach gospodarstwa rolnego zdaniem Autorów również może być uznana de facto za przedsiębiorstwo. W związku z działalnością turystyczną rolnicy są zmuszeni spojrzeć na swoją działalność bardziej rynkowo - uwzględniać potrzeby klientów, zidentyfikować i śledzić działania konkurentów i w tym aspekcie podjąć działania na rzecz przygotowania odpowiedniej oferty, jej promocji i skalkulowania ceny (Dorocki, Szymańska, Zdon-Korzeniowska, 2012). Podsumowując, działalność agroturystyczna (czy to zarejestrowana jako działalność gospodarcza czy też prowadzona w ramach gospodarstwa rolnego) jest działalnością gospodarczą, a jej podstawowym celem jest zysk (Sznajder, Przezbórska, 2009).

Badane przedsiębiorstwa agroturystyczne funkcjonowały w obydwu wymienionych wyżej formułach, a geneza ich powstania była różna. Część z nich powstała z przekształcenia gospodarstwa rolnego, część z nich prowadziła wcześniej inną działalność gospodarczą, a część od początku swego istnienia zaplanowana była jako działalność związana ze świadczeniem usług agroturystycznych. Szczegółowy rozkład wyników badań w tym zakresie zaprezentowano na rycinie 1 .

Jak wynika z badań, ponad $67 \%$ badanych przedsiębiorstw agroturystycznych powstało z przekształcenia gospodarstwa rolnego. W przypadku ponad 17\% wcześniej prowadzona była inna działalność pozarolnicza. Ponad 15\% podmiotów uczestniczących w badaniu od początku funkcjonowało jako gospodarstwa agroturystyczne (por. ryc. 1A). Pod względem

Ryc. 1. Geneza (A) oraz struktura działalności rolniczej (B) badanych gospodarstw agroturystycznych
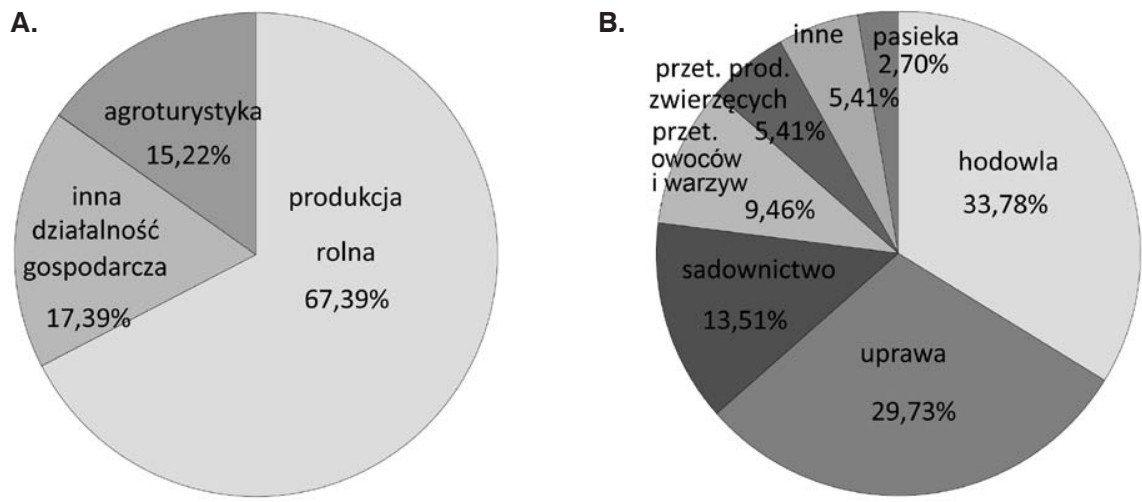

Źródło: opracowanie własne na podstawie wyników badań. 


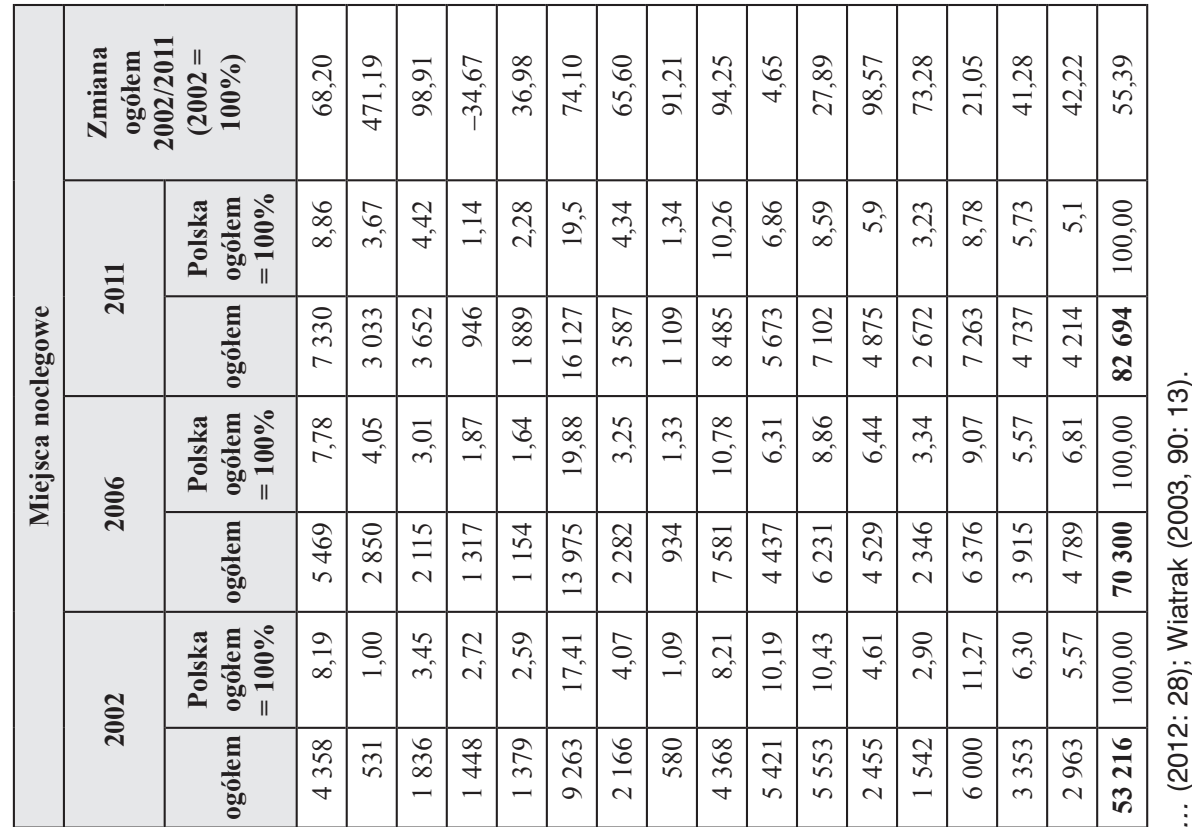

$\frac{\cdot \overline{2}}{\frac{2}{3}}$

3

包

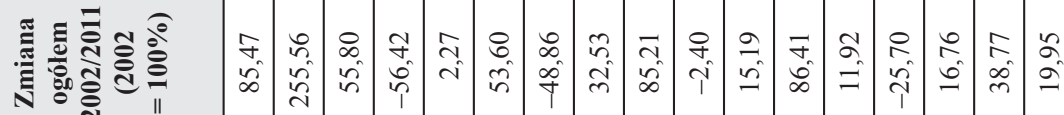

$\frac{1}{3}$

穴

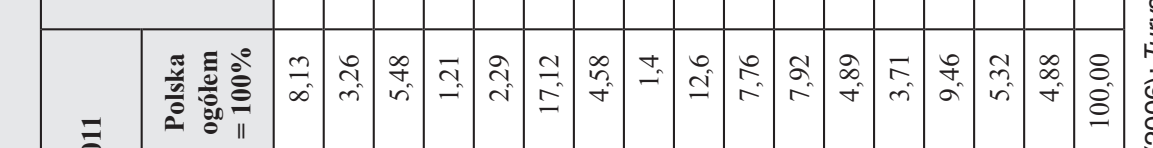

잉

¿

告

๘ ○ी

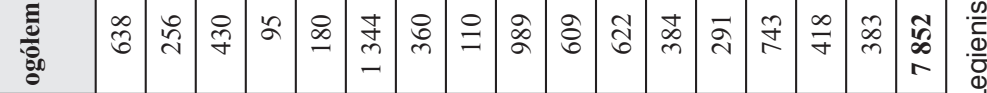

పे

들

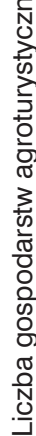

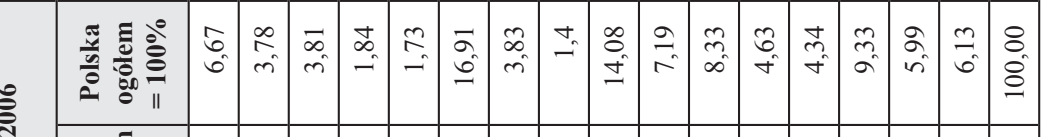

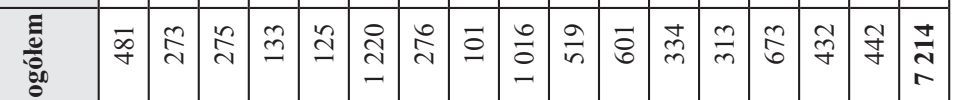

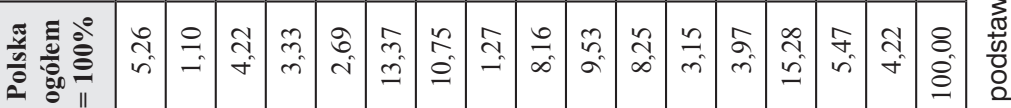

气ิ

\begin{tabular}{|c|c|c|c|c|c|c|c|c|c|c|c|c|c|c|c|c|c|}
\hline हूँ & 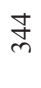 & $N$ & $\stackrel{\circ}{\imath}$ & $\frac{\infty}{\sim}$ & $\stackrel{゚}{\beth}$ & $\stackrel{n}{\infty}$ & $\stackrel{+}{?}$ & $\infty$ & 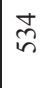 & $\stackrel{\mathbb{\sigma}}{\Delta}$ & if & $\stackrel{\text { ¿ }}{\circ}$ & $\stackrel{i}{i}$ & $\stackrel{8}{8}$ & $\stackrel{\infty}{n}$ & $\stackrel{0}{\curvearrowright}$ & $\begin{array}{l}0 \\
1 \\
1 \\
6\end{array}$ \\
\hline
\end{tabular}

$\frac{2}{0}$

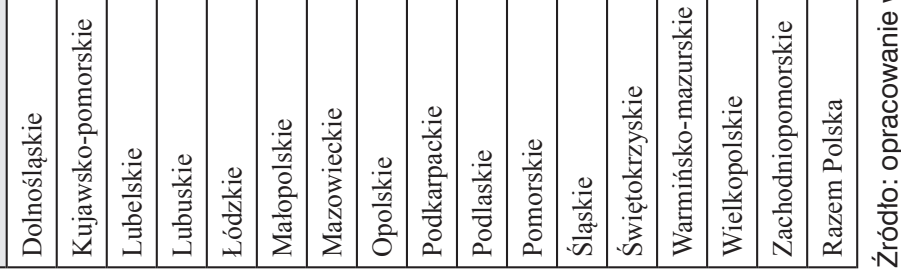


struktury działalności rolniczej w tych gospodarstwach, w których jest ona kontynuowana, to $\mathrm{w}$ przeważającej mierze wiąże się ona $\mathrm{z}$ hodowlą zwierząt $(33,78 \%)$ lub uprawą roślin (29,73\%). W ok. 13,5\% gospodarstw prowadzona jest działalność sadownicza, niespełna 10\% gospodarstw zajmuje się przetwórstwem owoców i warzyw, znacznie mniej przetwórstwem produktów zwierzęcych $(5,41 \%)$ i pszczelarstwem $(2,7 \%)$. W 5,41\% gospodarstw prowadzona jest inna niewymieniona wyżej działalność rolnicza (por. ryc. 1B).

\section{Skutki kryzysu w opinii gospodarstw agroturystycznych}

Okres spowolnienia gospodarczego dla przedsiębiorców jest czasem trudnym, ale i, jak zauważa A. Sawicka (2011), niezwykle mobilizującym. Zmusza on bowiem do rewizji celów oraz podjęcia zmian - zarówno w odniesieniu do zarządzania własnym przedsiębiorstwem, jak i w odniesieniu do rynku. Jak w czasie ostatnich kilku lat naznaczonych kryzysem gospodarczym poradziły sobie polskie gospodarstwa agroturystyczne? Czy dostrzegły, i w jakim zakresie, skutki dekoniunktury? Wspomniane we wstępie badania przeprowadzone na grupie gospodarstw agroturystycznych miały $\mathrm{m}$.in. na celu rozpoznanie, czy respondenci dostrzegają jakieś zmiany w funkcjonowaniu swojego gospodarstwa, a w efekcie, czy odczuwają w jakimś stopniu wpływ kryzysu gospodarczego na funkcjonowanie prowadzonych przez nich przedsiębiorstw agroturystycznych.

Jak wynika z przeprowadzonych badań, prawie 68\% respondentów dostrzegło zmiany w funkcjonowaniu swoich gospodarstw agroturystycznych w okresie ostatnich trzech lat, przy czym zdaniem 30,09\% były to zmiany pozytywnie wpływające na funkcjonowanie gospodarstwa, natomiast $31,74 \%$ dostrzegło zmiany negatywne (por. ryc. 2A i B).

Wśród pozytywnych zmian respondenci wymienili m.in. wzrost wysokości środków przeznaczonych na inwestycje (67\% badanych przedsiębiorstw - por. ryc. 3). W czasie kryzysu podmioty gospodarcze cechuje większa skłonność do oszczędzania niż inwestycji. Zwiększenie funduszy przeznaczonych przez gospodarstwa agroturystyczne na inwestycje może mieć dwojaką przyczynę: być może gospodarstwa te faktycznie nie poddały się pesymistycznym nastrojom i rzeczywiście inwestowały więcej lub pozyskiwały one na inwestycje fundusze unijne. Bez względu jednak na przyczynę tego stanu rzeczy zwiększone środki na inwestycje były zjawiskiem pozytywnym nie tylko dla badanych przedsiębiorstw agroturystycznych, ale i dla polskiej gospodarki.

Ryc. 2. Opinie gospodarstw agroturystycznych na temat dostrzegania zmian w ich funkcjonowaniu w okresie ostatnich trzech lat $(A)$ i na temat charakteru tych zmian (B)

A.

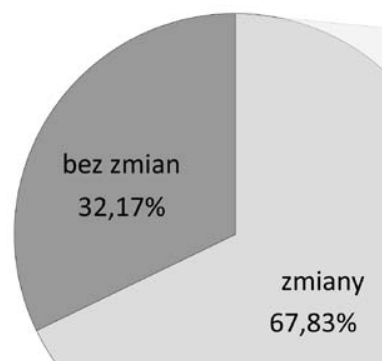

B.

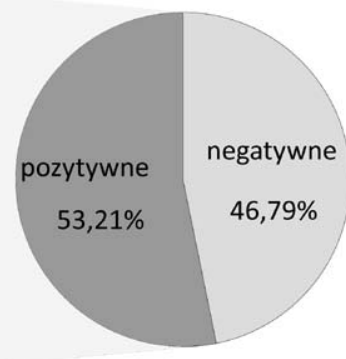

Źródło: wyniki badań własnych. 
Ryc. 3. Zmiany w funkcjonowaniu gospodarstw agroturystycznych zaobserwowane przez ich właścicieli w okresie ostatnich trzech lat
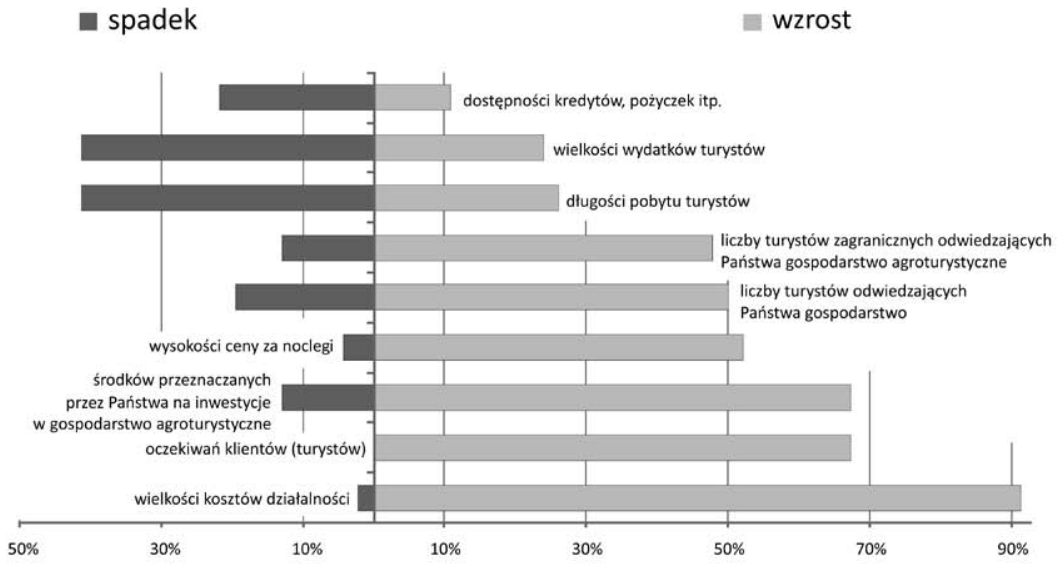

Źródło: wyniki badań własnych.

Wśród pozytywnych zmian zaobserwowanych przez badane podmioty był również wzrost liczby turystów odwiedzających gospodarstwa (50\% badanych), zwłaszcza turystów zagranicznych (47,8\% badanych). Choć jednocześnie odnotowano skrócenie czasu pobytu turystów w gospodarstwie (w 41,3\% przypadków) i wielkości ich wydatków (również w 41,3\% przypadków) oraz wzrost wymagań turystów (wg 67,4\% badanych gospodarstw) - co gospodarstwa odnotowały jako zjawiska dla nich niekorzystne. Najczęściej jednak wymienianym zjawiskiem niekorzystnym był wzrost kosztów działalności badanych przedsiębiorstw $(91,3 \%)$ oraz spadek dostępności kredytów i pożyczek (67\%). Pewną rekompensatą dla gospodarstw mógł być jednak zauważony przez ich właścicieli wzrost cen za oferowane usługi agroturystyczne $(52,2 \%$ gospodarstw).

Wśród innych pojedynczo podkreślanych zmian, jakie w ostatnich trzech latach zaszły w funkcjonowaniu gospodarstw agroturystycznych, wymieniano również następujące kwestie:

- nieprzeprowadzanie remontów,

- niepodnoszenie standardu tak jak w poprzednich latach,

- wzrost wydatków na promocję,

- wzrost opłat za wodę i ścieki,

- wzrost zainteresowania warsztatami i pokazami,

- zmiany w preferencjach żywieniowych (wzrost potrzeb klientów),

- wzrost cen żywności (wyżywienia).

Przeprowadzone badania pozwalają stwierdzić, że gospodarstwa agroturystyczne odczuły skutki dekoniunktury gospodarczej w swoim funkcjonowaniu w stosunkowo niedużym stopniu - de facto tylko nieco ponad 31\% gospodarstw dostrzegło negatywne zmiany. Najbardziej dotkliwymi były te związane ze wzrostem kosztów działalności. Większość gospodarstw nie zmniejszyła, a nawet zwiększyła swoje wydatki inwestycyjne, mimo dostrzeżonego spadku dostępności kredytów i pożyczek.

Jak się wydaje zatem, polskie gospodarstwa agroturystyczne nie uległy pesymistycznym nastrojom i dość dobrze poradziły sobie w okresie spadku koniunktury. Przyczyn tego stanu rzeczy możemy upatrywać w wielu czynnikach, m.in. w wielkości gospodarstw agroturystycznych, które najczęściej są mikro- lub co najwyżej małymi przedsiębiorstwami, odznaczającymi się przedsiębiorczością i elastycznością, tj. zdolnością dostosowywania się do zmieniających się 
warunków otoczenia (Zakrzewska-Bielawska, 2011a, 2011b). A, jak wskazuje A. Zakrzewska-Bielawska (2011b: 7), „umiejętność adaptacji jest niezwykle istotna w warunkach wahań cyklu koniunkturalnego, zwłaszcza w dobie kryzysu i spowolnienia gospodarczego".

Niebagatelne znaczenie w radzeniu sobie z kryzysem w przypadku gospodarstw agroturystycznych może mieć również ich rodzinny charakter. Owa rodzinność działalności gospodarczej wydaje się być, na podstawie uzyskanych wyników badań, dużym atutem i wsparciem dla funkcjonowania gospodarstw agroturystycznych w okresie dekoniunktury gospodarczej.

\section{Rodzinność i innowacyjność gospodarstw agroturystycznych a kryzys gospodarczy}

Działalność agroturystyczna ze względu na swoją specyfikę związaną ze świadczeniem usług turystycznych w oparciu o zasoby gospodarstwa rolnego lub równoważnego (często również domowego) jest od strony podażowej biznesem wybitnie rodzinnym. Niemal 100\% gospodarstw agroturystycznych możemy zakwalifikować do grona przedsiębiorstw o cechach „,rodzinności”. Nie wnikając w definicję pojęcia firma rodzinna, bez wątpienia należy stwierdzić, że przedsiębiorstwa tego typu ze względu na swój specyficzny charakter i związany z tym sposób funkcjonowania mogą liczyć na pewne, wynikające stąd „korzyści”, które wydają się być szczególnie istotne w czasach kryzysu gospodarczego. Pogląd ten potwierdzają gospodarstwa agroturystyczne uczestniczące w badaniach. Wypowiedź „W sytuacji kryzysowej bardziej można liczyć na wsparcie (również finansowe) członków rodziny niż osób do niej nienależących" uzyskała rangę 0,96 (tab. 2). Wsparcie to zdaniem badanych gospodarstw agroturystycznych wynika z wielu względów, m.in. z faktu, że:

- członkowie rodziny są bardziej zaangażowani w pracę gospodarstwa $(1,33)$,

- pracownicy będący członkami rodziny są bardziej lojalni $(1,56)$,

- członkowie rodziny bardziej angażują się w realizowane przedsięwzięcia $(1,54)$,

- członkowie rodziny bardziej dbają o zasoby majątkowe gospodarstwa $(1,48)$.

Niewątpliwie czynnikiem mobilizującym i sprzyjającym przetrwaniu w czasach kryzysu jest fakt, ,iż w przypadku przedsiębiorstw rodzinnych w znacznie większym stopniu niż w przypadku innych przedsiębiorstw ich właściciele patrzą w przyszłość, myśląc o sukcesji przedsiębiorstwa" (Dorocki, Szymańska, Zdon-Korzeniowska, 2012: 59). Perspektywa przejęcia przedsiębiorstwa w przyszłości przez następne pokolenia może wyzwalać w przedsiębiorcach dodatkowe siły mobilizujące podyktowane chęcią zapewnienia przyszłości swoim następcom.

Tab. 2. Opinie ankietowanych na temat wad i zalet płynących z prowadzenia działalności rodzinnej

\begin{tabular}{|c|c|c|}
\hline Lp. & Opinie ankietowanych & $\begin{array}{c}\text { Ocena } \\
\text { rangowa }\end{array}$ \\
\hline 1. & Członkowie rodziny są bardziej zaangażowani w pracę gospodarstwa. & 1,33 \\
\hline 2. & $\begin{array}{l}\text { Zarządzanie członkami rodziny jest znacznie łatwiejsze niż osobami } \\
\text { spoza niej. }\end{array}$ & 0,00 \\
\hline 3. & $\begin{array}{l}\text { Konflikty rodzinne/pokoleniowe przenoszone są na grunt zawodowy, } \\
\text { co utrudnia pracę. }\end{array}$ & $-0,52$ \\
\hline 4. & Członkowie rodziny bardziej dbają o zasoby majątkowe gospodarstwa. & 1,48 \\
\hline 5. & $\begin{array}{l}\text { W sytuacji kryzysowej bardziej można liczyć na wsparcie (również } \\
\text { finansowe) członków rodziny niż osób do niej nienależących. }\end{array}$ & 0,96 \\
\hline 6. & Członkowie rodziny bardziej angażują się w realizowane przedsięwzięcia. & 1,54 \\
\hline 7. & Pracownicy będący członkami rodziny są bardziej lojalni, godni zaufania. & 1,56 \\
\hline
\end{tabular}

Źródło: wyniki badań własnych. 
Poza elastycznością działania i potencjałem wynikającym z „rodzinności” niewielkich (mikroi małych) przedsiębiorstw do czynników sprzyjających walce i radzeniu sobie z kryzysem gospodarczym zaliczyć możemy również innowacyjność. Jak pokazują doświadczenia krajów wysoko rozwiniętych, „w zainicjowaniu innowacji i procesie ich rozpowszechniania dużą rolę odgrywają małe i średnie przedsiębiorstwa" (Lisowska, 2008: 35).

Zdaniem właścicieli gospodarstw agroturystycznych uczestniczących w badaniu starają się oni podejmować innowacyjne działania. Jednym z przejawów takiej postawy są innowacje produktowe. Aż $63 \%$ badanych przedsiębiorstw agroturystycznych zadeklarowało, że w ubiegłym roku wprowadziło jakąś nowość w ofercie. Pomysły w zakresie wprowadzanych zmian i nowości są zazwyczaj efektem sugestii gości (36,4\%), obserwacji działalności innych gospodarstw $(24,2 \%)$ lub stanowią pomysły własne albo członków rodziny (24,2\%). Najrzadziej inspiracją dla wprowadzanych nowości są pomysły zaczerpnięte ze szkoleń, w których uczestniczą pracownicy przedsiębiorstw agroturystycznych - stanowią one zaledwie 3,0\% ogółu wszystkich pomysłów na wprowadzane innowacje. Źródła innowacji produktowych w badanych gospodarstwach agroturystycznych zaprezentowano na rycinie 4 .

Ryc. 4. Źródła innowacji produktowych w gospodarstwach agroturystycznych

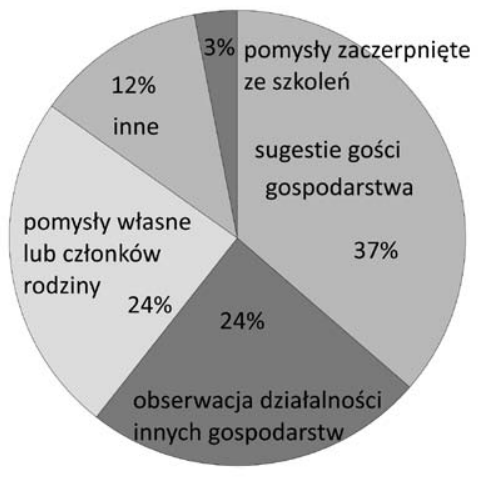

Źródło: wyniki badań własnych.

Podsumowując, należy podkreślić, że badane gospodarstwa agroturystyczne w stosunkowo niewielkim stopniu odczuły skutki dekoniunktury gospodarczej. Większość z nich w okresie trzech ostatnich lat nie odczuła żadnych zmian. Wśród wielu innych czynników taki stan rzeczy być może wynika również z faktu, że polska gospodarka w ogóle w niewielkim stopniu odczuła skutki ogólnoświatowego kryzysu gospodarczego. Najbardziej odczuwalną konsekwencją dekoniunktury gospodarczej w opinii właścicieli gospodarstw agroturystycznych, którzy w ogóle dostrzegli jakieś zmiany w okresie ostatnich trzech lat, był wzrost kosztów działalności - na fakt ten wskazało ponad $90 \%$ z nich.

Istotnym atutem gospodarstw agroturystycznych w walce z kryzysem gospodarczym wydaje się być ich rodzinny charakter. Bliskie więzi łączące współpracowników sprzyjają lepszej współpracy, efektywniejszej wymianie myśli i pomysłów, a w efekcie - większej innowacyjności podmiotów gospodarczych i większemu zaangażowaniu w działalność przedsiębiorstwa (związek emocjonalny, finansowy, poświęcony czas i wynikające stąd wsparcie emocjonalne czy finansowe, które uznać należy za szczególnie cenne w okresach dekoniunktury gospodarczej). 


\section{Literatura}

Dorocki, S., Rachwał, T., Szymańska, A.I., Zdon-Korzeniowska, M. (2012). Spatial Conditions for Agritourism Development on the Example of Poland and France. Current Issues of Tourism Research, 2(2), 20-29.

Dorocki, S., Szymańska, A.I., Zdon-Korzeniowska, M. (2012). Polskie gospodarstwa agroturystyczne jako przedsiębiorstwa rodzinne. Przedsiębiorczość i Zarządzanie, 8(8), 45-60.

Dorocki, S., Zdon-Korzeniowska, M. (2012). Agroturystyka jako alternatywna forma działalności rolniczej - przyktad Polski i Francji.

Lisowska, R. (2008). Bariery rozwoju działalności innowacyjnej małych i średnich przedsiębiorstw na terenach wiejskich na przykładzie województwa łódzkiego. W: N. Daszkiewicz (red.), Małe i średnie przedsiębiorstwa. Szanse i zagrożenia rozwoju, Warszawa: CeDeWu Sp. z o.o., 35-50.

Rachwał, T., Zdon-Korzeniowska, M. (2011). Turystyka w warunkach światowego kryzysu gospodarczego. Prace Komisji Geografii Przemystu Polskiego Towarzystwa Geograficznego, 18, 116-128.

Sawicka, A. (2011). Funkcjonowanie średnich firm w okresie spowolnienia gospodarczego. W: A. Zakrzewska-Bielawska, (red.), Wyzwania rozwojowe matych $i$ średnich przedsiębiorstw. Innowacje, technologie, kryzys, Warszawa: Difin, Warszawa, 255-269.

Sznajder, M., Przezbórska, L., (2006), Agroturystyka, PWE, Warszawa.

Zakrzewska-Bielawska, A. (2011a). Ocena innowacyjności małych i średnich przedsiębiorstw sektora ICT. W: A. Zakrzewska-Bielawska, (red.), Wyzwania rozwojowe matych i średnich przedsiębiorstw. Innowacje, technologie, kryzys, Warszawa: Difin, Warszawa, 37-53.

Zakrzewska-Bielawska, A. (2011b). Wprowadzenie. W: A. Zakrzewska-Bielawska, (red.), Wyzwania rozwojowe matych $i$ średnich przedsiębiorstw. Innowacje, technologie, kryzys, Warszawa: Difin, Warszawa, 7-8.

Sławomir Dorocki, dr, Uniwersytet Pedagogiczny im. Komisji Edukacji Narodowej w Krakowie, Instytut Geografii, Zakład Przedsiębiorczości i Gospodarki Przestrzennej

Absolwent studiów z zakresu geografii społeczno-ekonomicznej Uniwersytetu Pedagogicznego w Krakowie, doktor nauk humanistycznych w dyscyplinie historia (Instytut Europeistyki - Uniwersytet Jagielloński). Adiunkt w Instytucie Geografii Uniwersytetu Pedagogicznego w Krakowie. Zainteresowania badawcze skupiają się wokół problematyki regionów i procesów regionalizacji społeczno-gospodarczej, ze szczególnym uwzględnieniem zróżnicowania przestrzeni europejskiej oraz procesów integracji europejskiej i uwarunkowań historycznych.

Sławomir Dorocki, PhD, Pedagogical University of Cracow, Institute of Geography, Department of Entrepreneurship and Spatial Management.

Sławomir Dorocki graduated from the Pedagogical University in Cracow, with an MA in geography, and from the Jagiellonian University (Institute of European Studies), with a PhD in History. Adiunkt (assoc. professor) at the Pedagogical University in Cracow, Institute of Geography. Research interests include regional problems and processes of socio-economic regionalization, with particular emphasis on the diversity of Europe, processes of European integration and historical conditions.

Anna I. Szymańska, dr, Uniwersytet Pedagogiczny im. Komisji Edukacji Narodowej w Krakowie, Instytut Geografii, Zakład Przedsiębiorczości i Gospodarki Przestrzennej.

Absolwentka studiów magisterskich z zakresu zarządzania i marketingu Uniwersytetu Ekonomicznego w Krakowie, doktor nauk ekonomicznych w zakresie nauk o zarządzaniu (Katedra Analizy Rynku i Badań Rynkowych Uniwersytet Ekonomiczny w Krakowie). Adiunkt w Zakładzie Przedsiębiorczości i Gospodarki Przestrzennej Uniwersytetu Pedagogicznego w Krakowie. 
Jej zainteresowania naukowo-badawcze oscylują wokół problematyki potrzeb, preferencji i zachowań rynkowych konsumentów, jak również zagadnień z obszaru przedsiębiorczości i innowacyjności przedsiębiorstw ze szczególnym uwzględnieniem sektora MŚP.

Anna I. Szymańska, PhD, Pedagogical University of Cracow, Institute of Geography, Department of Entrepreneurship and Spatial Management.

Anna Irena Szymańska graduated from the University of Economics in Cracow, with a MA degree in Management and Marketing, a $\mathrm{PhD}$ degree in Economic Sciences in the field of management sciences (Department of Market Analysis and Marketing Research - University of Economics in Cracow). Adiunkt (assoc. professor) in Department of Entrepreneurship and Spatial Management at the Pedagogical University of Cracow. Research interests related to issues of consumer needs, preferences and market behaviour, as well as issues in areas of entrepreneurship and innovation, with particular emphasis on the SME sector.

Malgorzata Zdon-Korzeniowska

Malgorzata Zdon-Korzeniowska

Adres/Address: dr, Uniwersytet Pedagogiczny im. Komisji Edukacji Narodowej w Krakowie, Instytut Geografii, Zakład Przedsiębiorczości i Gospodarki Przestrzennej.

Absolwentka studiów magisterskich Uniwersytetu Ekonomicznego w Krakowie (kierunek: ekonomia, specjalność: przedsiębiorczość i innowacje), doktor nauk ekonomicznych w dyscyplinie nauk o zarządzaniu (Wydział Zarządzania i Komunikacji Społecznej Uniwersytetu Jagiellońskiego). Adiunkt w Zakładzie Przedsiębiorczości i Gospodarki Przestrzennej Instytutu Geografii Uniwersytetu Pedagogicznego w Krakowie. Jej zainteresowania naukowo-badawcze ogniskują się wokół problematyki zarządzania turystyką na poziomie lokalnym i regionalnym, ze szczególnym uwzględnieniem zrównoważonego rozwoju i budowy produktów turystycznych o charakterze lokalnym i regionalnym, a także integracji i koordynacji działań podmiotów zaangażowanych w ten proces, ze szczególnym uwzględnieniem roli samorządu terytorialnego.

MA in economy, $\mathrm{PhD}$ in economic sciences, Pedagogical University of Cracow, Institute of Geography, Department of Entrepreneurship and spatial Management. Małgorzata Zdon-Korzeniowska graduated from the Cracow University of Economics (Departament of Economics, specializing in Entrepreneurship and Innovation) with a MA degree in Economy, and from Faculty of Management and Social Communication, Jagiellonian University, Jagiellonian University, with a $\mathrm{PhD}$ in economic sciences in the discipline of management studies. Adiunkt (assoc. professor) at the Pedagogical University in Cracow, Institute of Geography, Department of Entrepreneurship and Spatial Management. Research interests center around the issues of tourism management at the local and regional level, with particular emphasis on sustainable development and the construction of local and regional tourist products, as well as the integration and coordination of the actors involved in this process, with particular emphasis on the role of local governments.

Uniwersytet Pedagogiczny im. Komisji Edukacji Narodowej w Krakowie ul. Podchorążych 2, 30-638 Kraków, Polska e-mail: sdorocki@up.krakow.pl; aszym@up.krakow.pl; mkorzen@up.krakow.pl 